\title{
Multi-Mycotoxin Screening Reveals the Occurrence of 139 Different Secondary Metabolites in Feed and Feed Ingredients
}

\author{
Elisabeth Streit ${ }^{1}$, Christina Schwab ${ }^{2, *}$, Michael Sulyok ${ }^{3}$, Karin Naehrer $^{2}$, Rudolf Krska ${ }^{3}$ and \\ Gerd Schatzmayr ${ }^{1}$
}

1 BIOMIN Research Center, Technopark 1, Tulln 3430, Austria;

E-Mails: elisabeth.streit@biomin.net (E.S.); gerd.schatzmayr@biomin.net (G.S.)

2 BIOMIN Holding GmbH, Industriestrasse 21, Herzogenburg 3130, Austria;

E-Mail: karin.naehrer@biomin.net

3 Center for Analytical Chemistry, Department for Agrobiotechnology (IFA-Tulln), University of Natural Resources and Life Sciences, Vienna (BOKU), Konrad-Lorenz-Str. 20, Tulln 3430, Austria; E-Mails: michael.sulyok@boku.ac.at (M.S.); rudolf.krska@boku.ac.at (R.K.)

* Author to whom correspondence should be addressed; E-Mail: christina.schwab@biomin.net; Tel.: +43-2782-803-320; Fax: +43-2782-803-40.

Received: 14 December 2012; in revised form: 7 February 2013 / Accepted: 22 February 2013 / Published: 8 March 2013

\begin{abstract}
The development of liquid chromatography-mass spectrometry (LC-MS)/mass spectrometry (MS) methods for the simultaneous detection and quantification of a broad spectrum of mycotoxins has facilitated the screening of a larger number of samples for contamination with a wide array of less well-known "emerging" mycotoxins and other metabolites. In this study, 83 samples of feed and feed raw materials were analysed. All of them were found to contain seven to 69 metabolites. The total number of detected metabolites amounts to 139. Fusarium mycotoxins were most common, but a number of Alternaria toxins also occurred very often. Furthermore, two so-called masked mycotoxins (i.e., mycotoxin conjugates), namely deoxynivalenol-3-glucoside (75\% positives) and zearalenone-4-sulfate (49\% positives), were frequently detected. Although the observed median concentrations of the individual analytes were generally in the low $\mu \mathrm{g} / \mathrm{kg}$ range, evaluating the toxicological potential of a given sample is difficult. Toxicity data on less well-known mycotoxins and other detected metabolites are notoriously scarce, as an overview on the available information on the most commonly detected metabolites shows. Besides, the possible synergistic effects of co-occurring substances have to be considered.
\end{abstract}


Keywords: emerging mycotoxins; masked mycotoxins; liquid chromatography; mass spectrometry; LC-MS/MS; mould

\section{Introduction}

Mycotoxins are a chemically diverse group of toxic secondary fungal metabolites that can occur in a wide array of commodities. Strictly speaking, they are defined as secondary metabolites of fungal origin exhibiting in vivo toxicity towards vertebrates after introduction via a natural route (i.e., ingestion, inhalation etc.) [1]. Contamination results from fungal infection and proliferation in the field or during storage [2,3]. Legal authorities, food and feed industry alike acknowledge the importance of this issue and considerable effort is directed towards detecting and preventing mycotoxin contamination. However, of the 300-400 mycotoxins known to date [4], only a very limited number is subject to legal guidance and regular monitoring. Regarding feed, aflatoxins (AF), fumonisins (FB), deoxynivalenol (DON), zearalenone (ZEN) and ochratoxin A (OTA) are most often tested for [2]. Still, many analytical methods used for the determination of fungal metabolites are specific for one mycotoxin or a closely related group of mycotoxins. Therefore, a separate analysis is required for each mycotoxin of interest, an important constraint for monitoring a large number of mycotoxins. The development of multi-mycotoxin LC-MS/MS methods was a major step towards overcoming this problem. A very powerful method was established by Sulyok et al. in 2006 [5] and has been continuously extended ever since [6,7]. The parameters for the detection of 186 metabolites have been published by Vishwanath et al. [8], and the same group has expanded the method to cover 320 fungal, bacterial and plant metabolites since then.

In addition to providing information on occurrence and concentration levels of an increasing number of usually neglected mycotoxins multi-mycotoxin LC-MS/MS methods also help to address the issue of masked mycotoxins. Masked mycotoxins are mycotoxin conjugates that typically remain undetected when testing for the parent toxin. They may be formed as part of the plant's defence mechanism (e.g., DON-3-glucoside or ZEN-4-glucoside), and in some cases, e.g., hidden fumonisins, masked mycotoxins even develop during food processing [9]. Apart from exerting toxic effects of their own there is evidence suggesting that some masked mycotoxins are reconverted into the parent toxin during digestion, further adding to the toxicity of the respective food or feed [10-13].

Ever since 2005, BIOMIN has conducted a survey program monitoring the worldwide prevalence and concentration of aflatoxins, fumonisins, deoxynivalenol, zearalenone and ochratoxin $\mathrm{A}$ in feed and feed raw materials [14-20]. Additionally, in an effort to further broaden the knowledge on mycotoxin occurrence and co-occurrence in feed, 83 samples were subjected to multi-mycotoxin LC-MS/MS analysis. The results are presented in this paper, including an overview of the currently available toxicity data for the most commonly detected "novel" or "emerging" mycotoxins (i.e., mycotoxins that have not received as much scientific attention as AF, FB, DON, ZEN and OTA). 


\section{Results}

A total number of 139 different fungal metabolites were detected in the 83 feed samples (Table 1). All of the samples were co-contaminated with seven to 69 different mycotoxins (Figure 1). The co-occurrence of 28 metabolites was most frequent, observed in $n=9$ of the samples. Figure 2 shows the distribution of the detected concentrations for metabolites that were detected in more than $60 \%$ of the samples.

Table 1. Mycotoxins and metabolites detected in the liquid chromatography-mass spectrometry (LC-MS)/ mass spectrometry (MS) analysed samples, specifying the number of positive samples $(n$ (pos)), the percentage of positive samples, as well as the median (positives) and the maximum concentration in $\mu \mathrm{g} / \mathrm{kg}$. In case there were only two positives, the range is provided instead; analytes are listed in order of prevalence.

\begin{tabular}{|c|c|c|c|c|c|c|c|c|c|}
\hline Mycotoxin/metabolite & $n$ (pos) & $\begin{array}{c}\% \\
\text { pos } \\
\end{array}$ & $\begin{array}{c}\text { Median } \\
(\mu \mathrm{g} / \mathrm{kg})\end{array}$ & $\begin{array}{c}\text { Max } \\
(\mu \mathrm{g} / \mathrm{kg})\end{array}$ & Mycotoxin/metabolite & $\begin{array}{c}n \\
\text { (pos) }\end{array}$ & $\begin{array}{c}\% \\
\text { pos } \\
\end{array}$ & $\begin{array}{c}\text { Median } \\
(\mu \mathrm{g} / \mathrm{kg})\end{array}$ & $\begin{array}{c}\text { Max } \\
(\mu \mathrm{g} / \mathrm{kg}) \\
\end{array}$ \\
\hline Beauvericin & 81 & 98 & 6.7 & 2326 & Pestalotin & 5 & 6 & 10 & 19 \\
\hline sum of Enniatins & 80 & 96 & 30 & 5441 & Tetracycline (ab) & 5 & 6 & 77 & 10,696 \\
\hline Enniatin A1 & 79 & 95 & 5.5 & 2216 & Versicolorin $\mathrm{C} * *$ & 5 & 6 & 0.8 & 89 \\
\hline Enniatin B & 76 & 92 & 11 & 780 & Amoxycillin * (ab) & 4 & 5 & NA & NA \\
\hline Enniatin B1 & 76 & 92 & 14 & 2690 & Andrastin D * & 4 & 5 & NA & NA \\
\hline Enniatin A & 72 & 87 & 0.8 & 1745 & Dechlorogriseofulvin & 4 & 5 & 18 & 182 \\
\hline Enniatin B2 & 8 & 10 & 0.8 & 13 & \multirow{2}{*}{ Griseofulvin } & \multirow{2}{*}{4} & \multirow{2}{*}{5} & \multirow{2}{*}{31} & \multirow{2}{*}{399} \\
\hline Enniatin B3 & 7 & 8 & 0.01 & 0.1 & & & & & \\
\hline Deoxynivalenol & 74 & 89 & 122 & 25,928 & Linamarin (plt) & 4 & 5 & 1705 & 20,205 \\
\hline Emodin & 74 & 89 & 9.8 & 1570 & Monoacetoxyscirpenol & 4 & 5 & 7.7 & 31 \\
\hline Equisetin & 72 & 87 & 23 & 13,680 & Neoxaline & 4 & 5 & 3.3 & 13 \\
\hline Zearalenone & 72 & 87 & 14 & 5326 & Penitrem A & 4 & 5 & 92 & 701 \\
\hline Aurofusarin & 70 & 84 & 85 & 17,659 & Roquefortine $\mathrm{C}$ & 4 & 5 & 103 & 915 \\
\hline Alternariol methyl ether & 68 & 82 & 1.4 & 733 & Secalonic acid D & 4 & 5 & 4.5 & 369 \\
\hline Alternariol & 66 & 80 & 2.8 & 221 & 3-AcetylDON & 3 & 4 & 28 & 588 \\
\hline Tentoxin & 66 & 80 & 3.9 & 76 & Agroclavin & 3 & 4 & 0.1 & 0.9 \\
\hline Moniliformin & 63 & 76 & 45 & 12,236 & Aminodecyl octadecanol & 3 & 4 & 39 & 276 \\
\hline DON-3-glucoside & 62 & 75 & 15 & 7764 & Cytochalasin J & 3 & 4 & 27 & 164 \\
\hline Culmorin & 61 & 63 & 195 & 44,616 & Ergocorninine & 3 & 4 & 14 & 15 \\
\hline Nivalenol & 61 & 63 & 17 & 1760 & Ergocristine & 3 & 4 & 47 & 63 \\
\hline Tryptophol & 59 & 71 & 267 & 99,040 & Ergocristinin & 3 & 4 & 21 & 25 \\
\hline Apicidin & 55 & 66 & 1.9 & 160 & Ergocryptine & 3 & 4 & 16 & 25 \\
\hline Brevianamide $\mathrm{F}$ & 54 & 65 & 69 & 2043 & Ergocryptinine & 3 & 4 & 8.8 & 11 \\
\hline Tenuazonic acid & 54 & 65 & 68 & 1983 & Ergosin & 3 & 4 & 27 & 52 \\
\hline 15-Hydroxyculmorin & 52 & 63 & 49 & 15,620 & Ergosinin & 3 & 4 & 4.8 & 8.6 \\
\hline Butenolide & 43 & 52 & 23 & 1490 & Ergotamine & 3 & 4 & 71 & 129 \\
\hline ZEN-4-sulfate & 41 & 49 & 1 & 136 & Ergotaminine & 3 & 4 & 9.7 & 18 \\
\hline Altertoxin-I & 35 & 42 & 1.1 & 65 & Lotaustralin (plt) & 3 & 4 & 50 & 435 \\
\hline Curvularin & 29 & 35 & 14 & 484 & Ochratoxin A & 3 & 4 & 4.9 & 31 \\
\hline
\end{tabular}


Table 1. Cont.

\begin{tabular}{|c|c|c|c|c|c|c|c|c|c|}
\hline Mycotoxin/metabolite & $n$ (pos) & $\begin{array}{c}\% \\
\text { pos }\end{array}$ & $\begin{array}{r}\text { Median } \\
(\mu \mathrm{g} / \mathrm{kg})\end{array}$ & $\begin{array}{c}\text { Max } \\
(\mu \mathrm{g} / \mathrm{kg})\end{array}$ & Mycotoxin/metabolite & $\begin{array}{c}n \\
(\text { pos }) \\
\end{array}$ & $\begin{array}{c}\% \\
\text { pos }\end{array}$ & $\begin{array}{c}\text { Median } \\
(\mu \mathrm{g} / \mathrm{kg})\end{array}$ & $\begin{array}{c}\text { Max } \\
(\mu \mathrm{g} / \mathrm{kg})\end{array}$ \\
\hline Avenacin $\mathrm{Y}$ & 26 & 31 & 209 & 9948 & Paspalitrem A* & 3 & 4 & NA & NA \\
\hline Macrosporin A & 26 & 31 & 3.3 & 9.1 & Rubellin D & 3 & 4 & 259 & 1188 \\
\hline T-2 Toxin & 26 & 31 & 3.8 & 427 & Rubrofusarin & 3 & 4 & 2374 & 4923 \\
\hline Macrosporin & 24 & 29 & 3.7 & 15 & T-2 Tetraol & 3 & 4 & 9.5 & 1655 \\
\hline Monocerin & 24 & 29 & 0.9 & 2644 & sum of Aflatoxins & 2 & 2 & $0.24^{\mathrm{a}}$ & 861 \\
\hline Siccanol * & 23 & 28 & 9607 & 39850 & Aflatoxin $\mathrm{B}_{1}$ & 2 & 2 & $0.24^{\mathrm{a}}$ & 699 \\
\hline 3-Nitropropionic acid & 19 & 23 & 6 & 392 & Aflatoxin $\mathrm{B}_{2}$ & 1 & 1 & - & 63 \\
\hline sum of Fumonisins & 18 & 22 & 203 & 57,667 & Aflatoxin $\mathrm{G}_{1}$ & 1 & 1 & - & 69 \\
\hline Fumonisin $\mathrm{B}_{1}$ & 18 & 22 & 142 & 40,300 & Aflatoxin $\mathrm{G}_{2}$ & 1 & 1 & - & 4.4 \\
\hline Fumonisin $\mathrm{B}_{2}$ & 18 & 22 & 38 & 10,372 & Aflatoxin $\mathrm{M}_{1}$ & 1 & 1 & - & 26 \\
\hline Fumonisin $\mathrm{B}_{3}$ & 14 & 17 & 18 & 3859 & Cyclopiazonic acid & 2 & 2 & $37^{\mathrm{a}}$ & 2319 \\
\hline Fumonisin $\mathrm{B}_{4}$ & 7 & 8 & 112 & 3136 & Diacetoxyscirpenol & 2 & 2 & $0.04^{\mathrm{a}}$ & 2.7 \\
\hline Fusaric acid & 18 & 22 & 643 & 13,593 & Ergocornine & 2 & 2 & $19^{\mathrm{a}}$ & 25 \\
\hline HT-2 Toxin & 18 & 22 & 13 & 1910 & Ergocristam * & 2 & 2 & $17,370^{\mathrm{a}}$ & 19230 \\
\hline Chrysophanol & 17 & 20 & 8.2 & 41 & Ergocristinam * & 2 & 2 & $7181^{a}$ & 8233 \\
\hline Mycophenolic acid & 17 & 20 & 40 & 21,856 & Ergovalin & 2 & 2 & $1^{\mathrm{a}}$ & 5.4 \\
\hline Averufin ** & 16 & 19 & 0.4 & 215 & Gibberellic acid & 2 & 2 & $9.7^{\mathrm{a}}$ & 89 \\
\hline$\beta$-Zearalenol & 15 & 18 & 5.1 & 174 & Methylsterigmatocystin & 2 & 2 & $0.4^{\mathrm{a}}$ & 27 \\
\hline Bikaverin * & 14 & 17 & 27510 & 51,130 & Neosolaniol & 2 & 2 & $0.7^{\mathrm{a}}$ & 290 \\
\hline Fusaproliferin & 14 & 17 & 2555 & 14,844 & Penicillic acid & 2 & 2 & $12^{\mathrm{a}}$ & 13 \\
\hline Fusarinolic acid $* *$ & 13 & 16 & 643 & 13,965 & Radicicol & 2 & 2 & $5.3^{\mathrm{a}}$ & 5.9 \\
\hline Skyrin & 13 & 16 & 1.4 & 6853 & Terphenyllin & 2 & 2 & $16^{\mathrm{a}}$ & 67 \\
\hline Chlamydosporol & 12 & 14 & 55 & 656 & 15-AcetylDON & 1 & 1 & - & 2718 \\
\hline 5-Hydroxyculmorin & 11 & 13 & 350 & 3920 & Aflatrem * & 1 & 1 & NA & NA \\
\hline$\alpha$-Zearalenol & 11 & 13 & 2 & 51 & Averantin & 1 & 1 & - & 20 \\
\hline Ergometrinin & 11 & 13 & 0.3 & 14 & Averufanin ** & 1 & 1 & - & 29 \\
\hline Kojic acid & 10 & 12 & 75 & 3172 & Calphostin C & 1 & 1 & - & 431 \\
\hline Chanoclavin & 8 & 10 & 0.1 & 8.9 & Citrinin & 1 & 1 & - & 42 \\
\hline Andrastin A* & 7 & 8 & 4814 & 7603 & Cycloaspeptide A & 1 & 1 & - & 4.6 \\
\hline Physcion & 7 & 8 & 245 & 1162 & Cytochalasin B & 1 & 1 & - & 27 \\
\hline Sterigmatocystin & 7 & 8 & 1.5 & 4.7 & Cytochalasin $\mathrm{H}$ & 1 & 1 & - & 77 \\
\hline 15-Hydroxyculmoron & 6 & 7 & 83 & 4886 & Decalonectrin & 1 & 1 & NA & NA \\
\hline Aspterric acid & 6 & 7 & 194 & 3992 & Erginie & 1 & 1 & - & 0.33 \\
\hline hydrolysed $\mathrm{FB}_{1}$ & 6 & 7 & 15 & 95 & Festucalvin & 1 & 1 & - & 0.34 \\
\hline Paspalin * & 6 & 7 & NA & NA & Malformin A ** & 1 & 1 & - & 8 \\
\hline Sambucinol & 6 & 7 & 149 & 675 & Malformin C & 1 & 1 & - & 2.7 \\
\hline Citreoviridin & 5 & 6 & 94 & 382 & Nidurufin $* *$ & 1 & 1 & - & 9 \\
\hline Ergometrin & 5 & 6 & 6.8 & 26 & Norsolorinic acid $* *$ & 1 & 1 & - & 1.6 \\
\hline Lycomycin * & 5 & 6 & NA & NA & Pyrenophorol & 1 & 1 & - & 13 \\
\hline Meleagrin & 5 & 6 & 237 & 1821 & Rugulosin & 1 & 1 & - & 201,640 \\
\hline Oxytetracyclin & 5 & 6 & NA & NA & T-2 Triol & 1 & 1 & - & 278 \\
\hline Paxillin & 5 & 6 & 5017 & 94,860 & Versicolorin A $* *$ & 1 & 1 & - & 27 \\
\hline
\end{tabular}

a minimum in $\mu \mathrm{g} / \mathrm{kg}$; * no standard available for quantification (if a standard became available at some point, the results samples analysed thereafter are shown in the median/maximum column); ** semi-quantified using response factor of a structurally related analyte; ab: antibiotic, plt: plant metabolite, NA: not applicable. 
Figure 1. Number of samples co-contaminated with a given number of mycotoxins and/or metabolites.

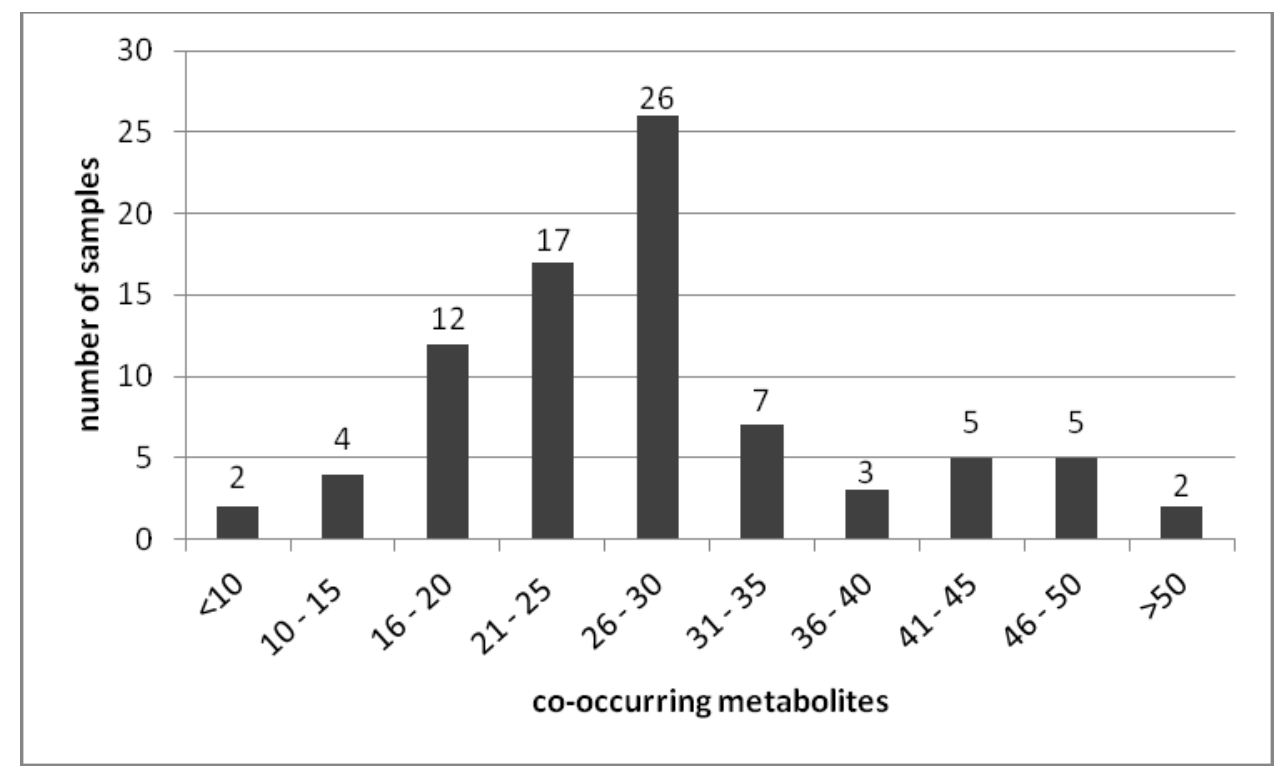

Beauvericin (BEA) was found most often. It was detected in $98 \%$ of the samples. Enniatins (ENN) were second most common, with $96 \%$ of the samples testing positive followed by DON and emodin with $89 \%$ positives each.

Figure 2. Distribution of the concentrations of metabolites detected in more than $60 \%$ of the samples; median (right side line, ${ }^{-}$) and average (continuous line, - ) concentration are given as well.

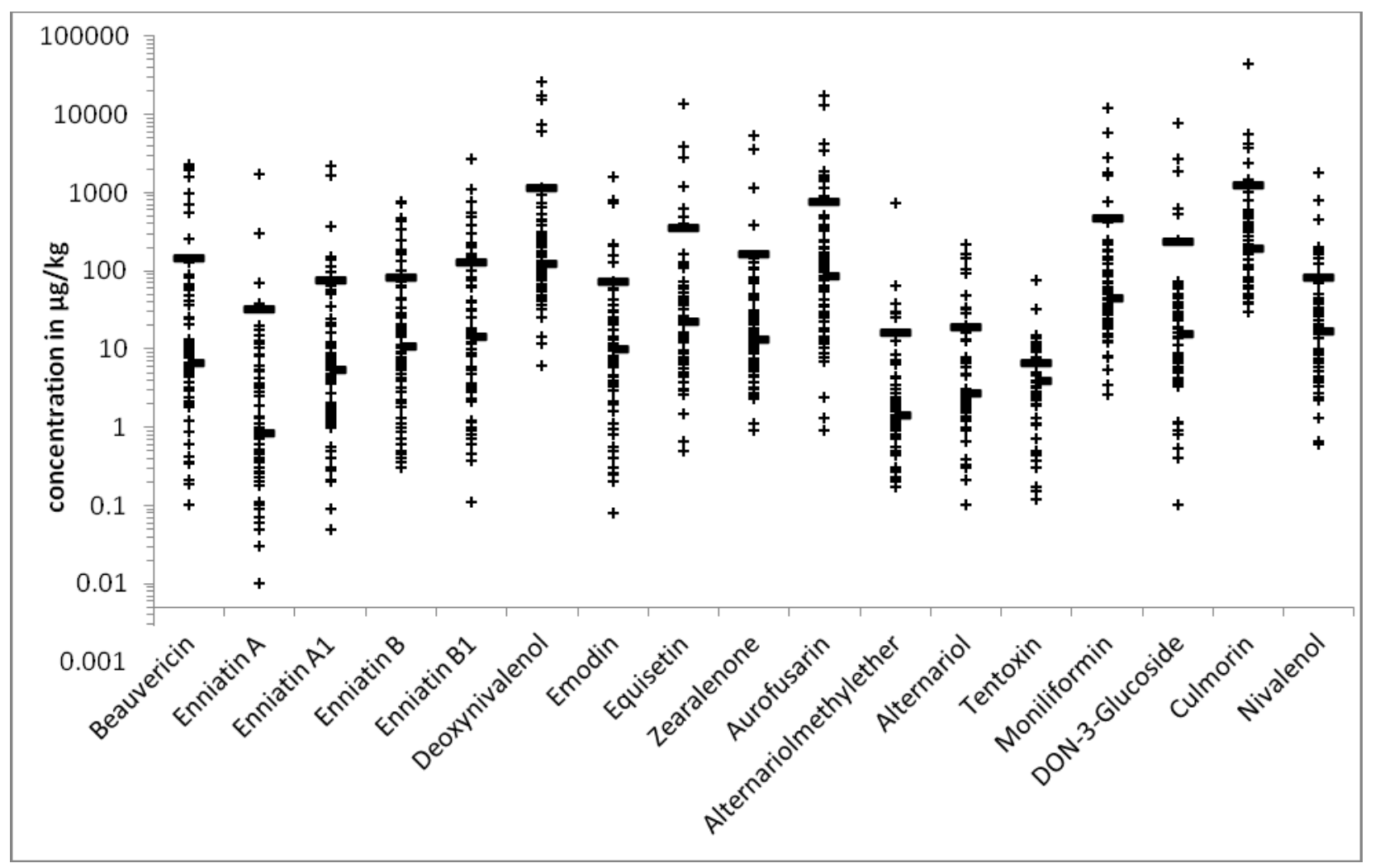


The samples listed in Table 1 include six maize cob samples from Lower Austria that all had visible signs of mould infection, ranging from slightly infected $(n=4)$ to severely moulded $(n=2)$. Two of those samples were obtained in 2010 and the other four in 2012. All samples were acquired directly after harvest. The results per sample are specified in Table 2.

Table 2. Analytes detected in six maize cob samples from Lower Austria, showing different degrees of mould infection.

\begin{tabular}{|c|c|c|c|c|c|c|}
\hline \multirow{2}{*}{ Mycotoxin/metabolite } & \multicolumn{6}{|c|}{ Samples, concentrations in $\mu \mathrm{g} / \mathrm{kg}$} \\
\hline & 2010-1 * & 2010-2 & 2012-1 & 2012-2 & 2012-3 & $2012-4 *$ \\
\hline 15-acetyl-DON & - & - & - & - & - & 2718 \\
\hline 15-Hydroxyculmorin & - & - & - & - & - & 4634 \\
\hline 3-acetyl-DON & - & - & - & - & - & 588 \\
\hline$\alpha$-Zearalenol & - & - & - & - & - & 35 \\
\hline Apicidin & 0.03 & 22 & 2 & - & - & - \\
\hline Aurofusarin & 240 & 3380 & 1.3 & 44 & 0.9 & 17,659 \\
\hline Avenacin $\mathrm{Y}$ & 1210 & - & - & - & - & - \\
\hline Beauvericin & 1390 & 970 & 1591 & 64 & 699 & 57 \\
\hline$\beta$-Zearalenol & - & - & - & - & - & 174 \\
\hline Bikaverin & - & - & detected & detected & detected & detected \\
\hline Butenolide & 167 & 1490 & 32 & 167 & - & 569 \\
\hline Culmorin & - & - & - & - & - & 44,616 \\
\hline Decalonectrin & - & - & - & - & - & detected \\
\hline Deoxynivalenol & 12 & 43 & 65 & 48 & 36 & 25,928 \\
\hline Diacetoxyscirpenol & 0.04 & 2.7 & - & - & - & - \\
\hline DON-3-glucoside & - & 0.5 & 0.1 & - & 0.1 & 7764 \\
\hline Enniatin A & 301 & 0.6 & - & 8.3 & - & - \\
\hline Enniatin A1 & 1670 & 4.9 & 0.4 & 83 & 0.3 & 0.5 \\
\hline Enniatin B & 780 & 3.9 & 0.6 & 64 & 0.3 & 0.3 \\
\hline Enniatin B1 & 2690 & 9.8 & 1 & 166 & 0.7 & 0.8 \\
\hline Equisetin & - & - & - & - & 4.4 & 1.5 \\
\hline Fusaproliferin & 1970 & 46 & 14,844 & 975 & 5029 & - \\
\hline Fusaric acid & - & - & 2146 & 1155 & 1426 & 85 \\
\hline Fusarinolic acid & - & - & 9405 & 440 & 3960 & 1936 \\
\hline Gibberellic acid & - & - & 9.7 & - & - & - \\
\hline Moniliformin & 5750 & 1650 & 2809 & 244 & 1,779 & 231 \\
\hline Monoacetoxyscirpenol & 0.64 & 6.1 & - & - & - & - \\
\hline Nivalenol & 147 & 1760 & 2.3 & - & - & 41 \\
\hline Pestalotin & - & - & 2.2 & 19 & 10 & - \\
\hline Sambucinol & - & - & - & - & - & 181 \\
\hline Siccanol & - & - & detected & detected & detected & detected \\
\hline Skyrin & - & 10 & - & - & - & - \\
\hline Tentoxin & - & - & 0.5 & 2.8 & - & - \\
\hline Tenuazonic acid & - & - & 499 & 134 & - & 133 \\
\hline Zearalenone & - & - & - & - & - & 5326 \\
\hline ZEN-4-sulfate & - & - & - & - & - & 136 \\
\hline
\end{tabular}

* Heavily moulded. 
The six maize cob samples were co-contaminated with 15 to 25 metabolites, which are below the average of 28 co-occurring metabolites observed in the pool of samples as a whole. Great differences were observed regarding the mycotoxin concentrations and contamination pattern depending on the year of analysis. Mono- and di-acetoxyscirpenol for example were only detected in the 2010 samples, while tentoxin and tenuazonic acid were only detected in 2012 (bikaverin, fusaric acid, fusarinolic acid and siccanol were not covered by the 2010 method). Nivalenol levels were higher in 2010, while fusaproliferin concentrations were more elevated in 2012 (sample 2010-2 had the highest nivalenol concentration, and sample 2012-1 had the highest fusaproliferin concentration of all 83 samples). It is interesting to note that the mycotoxin levels and contamination pattern were quite different for samples sourced in the same year as well in some cases. The enniatin concentrations in the heavily moulded cob from 2010 (2010-1) were many times higher than those detected in the other samples. This sample also contained higher levels of fusaproliferin or moniliformin than the other 2010 sample, but had much lower levels of aurofusarin, mono- and di-acetoxyscirpenol or nivalenol. Sample 2012-4 (severe mould infection), for example, contained much higher levels of aurofusarin, DON and DON-3-glucoside than any of the other samples and was the only sample contaminated with 3 -acetyl-DON, 15-acetyl-DON, 15-hydroxyculmorin, $\alpha$-zearalenol, $\beta$-zearalenol, culmorin, ZEN or ZEN-4-sulfate. In fact, the observed concentrations of DON, ZEN, aurofusarin, DON-3-glucoside, ZEN-4-sulfate and 3-acetyl-DON in this sample were the highest in the entire study. On the other hand, it did not contain fusaproliferin, which was present at rather high concentrations in the other three samples from 2012. These results suggest that the fungal populations on a given year's cobs were different, despite the fact that the cobs were obtained from the same field.

Furthermore, the pool of samples includes three US maize samples that were selected for LC-MS/MS analysis after "conventional" high-performance liquid chromatography (HPLC) analysis showed a high contamination with $\mathrm{DON}(n=2)$ or fumonisins and aflatoxins $(n=1)$. This was done in order to identify co-occurring metabolites in samples with excessively high concentrations of regulated mycotoxins. Both samples with high DON levels $(17,360$ and 15,684 $\mu \mathrm{g} / \mathrm{kg}$ ) also had high levels of DON-3-glucoside (2696 and $1977 \mu \mathrm{g} / \mathrm{kg}$ ), aurofusarin (4155 and 12,908 $\mu \mathrm{g} / \mathrm{kg}$ ), ZEN (1137 and $378 \mu \mathrm{g} / \mathrm{kg}$ ) and ZEN-4-sulfate (61 and $26 \mu \mathrm{g} / \mathrm{kg}$ ). Fumonisin levels were low in both samples (sum of fumonisins: 35 and $56 \mu \mathrm{g} / \mathrm{kg}$ ). The latter sample also had the highest concentration of 15-hydroxyculmorin detected in this study. The samples were co-contaminated with 11 and 45 metabolites, respectively. The aflatoxin and fumonisin contaminated sample tested positive for 69 metabolites. Apart from containing the highest aflatoxin and fumonisin levels observed in this study, it also had the highest level of cyclopiazonic acid, moniliformin and fusarinolic acid. Furthermore, $49 \mu \mathrm{g} / \mathrm{kg}$ alternariol, $39 \mu \mathrm{g} / \mathrm{kg}$ alternariol methyl ether and $30 \mu \mathrm{g} / \mathrm{kg}$ OTA were detected amongst others. DON and ZEN concentrations were low in this sample ( 79 and $3 \mu \mathrm{g} / \mathrm{kg}$, respectively).

\section{Discussion}

The results of the analysis of 83 samples with a multi-mycotoxin method based on LC-MS/MS clearly show that mycotoxin co-contamination is the rule. Mixtures of Fusarium toxins are detected most frequently, which is in line with the findings of two other studies using the same LC-MS/MS method on African food and feed samples [21,22]. Given the fact that Fusarium species are plant 
pathogens of major importance worldwide, particularly in cereal production, this is not surprising. Their occurrence in cereals and feed on a global scale was reviewed by Placinta et al. [23]. Bottalico [24] published an extensive review on the occurrence of various Fusarium spp. in Europe, including their mycotoxin profiles. Most species were reported to simultaneously produce a number of mycotoxins. Additionally, crops are almost always infected by several different fungal species at once. Bottalico [24] stated that it was quite common to isolate up to nine different Fusarium spp. from a single piece of infected tissue. Taken together, these facts explain the high prevalence of Fusarium mycotoxins in the analysed samples.

Except for specifically selected high contamination samples, the concentrations of individual mycotoxins were generally low and almost always well below the respective EC maximum level or guidance value (maximum levels exist for aflatoxin $\mathrm{B} 1\left(\mathrm{AFB}_{1}\right)$ [25], guidance values exist for $\mathrm{DON}$, ZEN, FB1 + FB2 and OTA [26]) in feed. As for DON, the frequent detection of DON-3-glucoside (DON-3-Glc) should be mentioned. It always co-occurred with DON and was detected in $75 \%$ of the samples. Given that several lactic acid bacteria commonly found in the digestive tract of mammals were recently reported capable of cleaving a significant proportion of DON-3-Glc, releasing DON [12], the presence of DON-3-Glc is likely to increase the total bio available amount of DON in contaminated feed. In this study, DON-3-Glc was detected at concentrations attaining on average 12\% of the DON contamination level of the respective sample. This percentage is in line with the findings of De Boevre et al. [27], who reported that DON-3-Glc accounted for up to $14 \%$ of the average total DON equivalents detected in feed samples. Nevertheless, even supposing the unlikely event of a $100 \%$ conversion of DON-3-Glc to DON during digestion and disregarding specifically selected high contamination samples, only two wheat samples came close to surpassing the respective European Commission (EC) guidance value. Recent results obtained from rat studies suggest, however, that the bioavailability of DON-3-Glc is low [28]. ZEN-4-sulfate (ZEN-4-S), a masked form of ZEN, was also detected frequently. This mycotoxin conjugate is readily hydrolysed in acidic conditions [11]. Hence, ZEN is released during digestion of ZEN-4-S contaminated diets.

Concerning the mycotoxins other than DON and ZEN listed in Table 1, data on toxicity, especially in vivo data, are scarce. Available data are summarised in Table 3. BEA and ENN exhibit low acute toxicity in vivo [29]. It is, however, unclear to what extent they influence the toxic effects of other mycotoxins. BEA in particular was reported to be a chemo sensitising agent with the potential to increase the efficacy of antibiotics, as well as chemotherapeutic anti-cancer drugs [29].

Emodin has also been investigated for its pharmacologic properties. It is a major chemical constituent of Chinese rhubarb (Rheum palmatum) roots and has been reported to exert anti-inflammatory, anti-arteriosclerotic and immunosuppressive effects. Furthermore, it inhibits the proliferation of various cancer cell lines [30], increases the effect of gemcitabine on pancreatic cancer in mice [31] and has been proposed as possible treatment for type-2 diabetes [32]. 
Table 3. Producing species, effects and toxicities of less well-known mycotoxins and other metabolites detected in more than $45 \%$ of the samples.

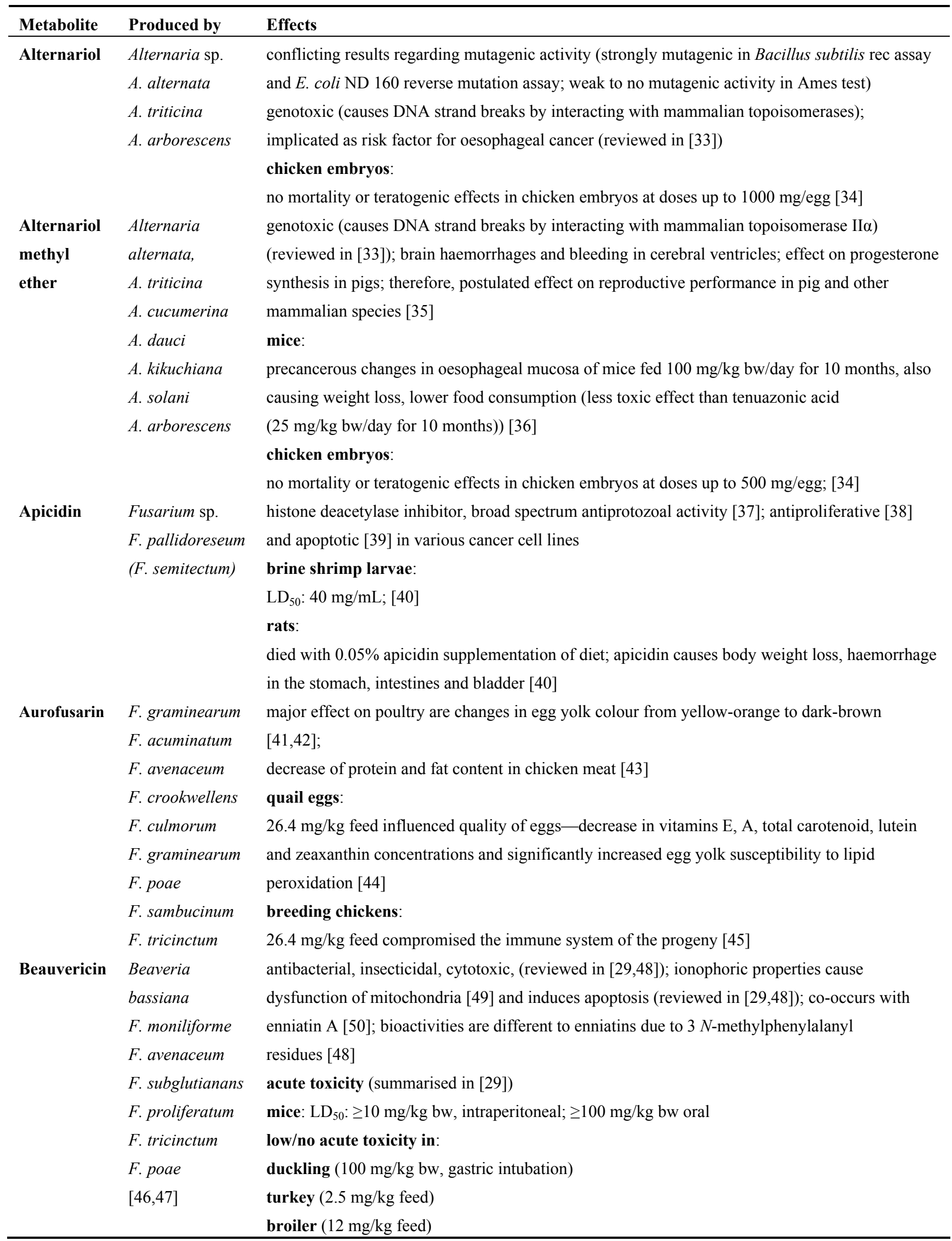


Table 3. Cont.

\begin{tabular}{|c|c|c|}
\hline Metabolite & Produced by & Effects \\
\hline $\begin{array}{l}\text { Brevianamide } \\
\text { F }\end{array}$ & $\begin{array}{l}\text { Penicillium } \\
\text { brevicompactum } \\
\text { Aspergillus } \\
\text { versicolor } \\
\text { A. fumigatus }\end{array}$ & $\begin{array}{l}\text { antibacterial, [51] } \\
\text { precursor of the fumitremorgins and the tryprostatins [51,52] } \\
\text { also produced by Streptomyces sp.[53] }\end{array}$ \\
\hline Butenolide & $\begin{array}{l}\text { Fusarium } \\
\text { crookwellense } \\
\text { F. culmorum } \\
\text { F. graminearum } \\
\text { F. poae } \\
\text { F. moniliformin }\end{array}$ & $\begin{array}{l}\text { myocardial oxidative damage; [54] oxidative injuries in chick embryonic livers and kidneys [55]; } \\
\text { growth retardation and differentiation inhibition in vitro in rat embryos [56]; probably implicated } \\
\text { in fescue foot disease [57]; anti-marine-fouling compound - toxic to zebra fish embryos by } \\
\text { inducing apoptosis [58] } \\
\text { mice: } \mathrm{LD}_{50}: 44 \mathrm{mg} / \mathrm{kg} \mathrm{bw} \text {, intraperitoneal; } 275 \mathrm{mg} / \mathrm{kg} \text { bw oral [59] } \\
\text { steers: } \\
\text { died after } 68 \text { and } 39 \mathrm{mg} / \mathrm{kg} \text { for } 2 \text { and } 3 \text { days oral dosage; with smaller dosage, development of } \\
\text { petechial haemorrhages and acute inflammation of gastric compartments ([60] in [59]) }\end{array}$ \\
\hline Culmorin & $\begin{array}{l}\text { F. culmorum, } \\
\text { F. graminearum } \\
\text { F. poae } \\
\text { F. langsethiae } \\
\text { F. cerealis }\end{array}$ & $\begin{array}{l}\text { low toxicity in several in vitro assays, Ames test negative [61], co-occurrence with DON [62] } \\
\text { swine: } \\
\text { some minor non-significant effects on growth and feed consumption ( } 2 \mathrm{mg} / \mathrm{kg} \text { feed) with and } \\
\text { without DON ( } 6 \mathrm{mg} / \mathrm{kg} \text { feed) [63] }\end{array}$ \\
\hline $\begin{array}{l}\text { 15- } \\
\text { Hydroxy- } \\
\text { culmorin }\end{array}$ & $\begin{array}{l}\text { F. graminearum } \\
\text { F. culmorum } \\
\text { F. poae }\end{array}$ & $\begin{array}{l}\text { co-occurrence with culmorin and DON [64] } \\
\text { no evidence of acute toxicity to mammals so far [65] }\end{array}$ \\
\hline Emodin & $\begin{array}{l}\text { A. wentii } \\
\text { A. flavus } \\
\text { A. ocharaceus } \\
\text { Plants: } \\
\text { rhubarb root }\end{array}$ & $\begin{array}{l}\text { possibly genotoxic [66]; cytotoxic, antitumour, antibacterial, anti-inflammatory, } \\
\text { immunosuppressive [30] } \\
\text { active ingredient of various Chinese herbs, potential drug for therapy of type-2 diabetes [32] } \\
\text { mice: induces embryonic toxicity in mouse blastocysts through apoptosis; [30] } \\
\text { 1-day-old cockerels: } \mathrm{LD}_{50}: 3.7 \mathrm{mg} / \mathrm{kg} \text { bw [67] } \\
\text { clinical symptoms in cockerels included loss of appetite, accumulation of faecal material with } \\
\text { acute epidermal irritation around the cloaca, general debilitation and mortality within } 5 \text { days of } \\
\text { ingestion; } \\
\text { zebrafish embryos: } \\
0.25 \mu \mathrm{g} / \mathrm{mL} \text { negatively affected embryo survival and hatching success; toxic to larvae at } \\
\text { relatively low concentrations [68] }\end{array}$ \\
\hline Enniatin A & F. moniliforme & antibacterial, antifungal, herbicidal, insecticidal, ionophore, induction of apoptosis $[29,49,69,70]$ \\
\hline Enniatin & F. avenaceum & enniatin B often occurs together with enniatin B1 and enniatin A with beauvericin [50] \\
\hline A1 & F. roseum & mice: $10-40 \mathrm{mg} / \mathrm{kg}$ bw, intraperitoneal, every $8 \mathrm{~h}$ : mice died within $2-5$ days; \\
\hline Enniatin B & F. solani & doses $<10 \mathrm{mg} / \mathrm{kg}$ bw resulted in reduced body weight [71] \\
\hline Enniatin B1 & $\begin{array}{l}\text { F. nivale } \\
\text { F. acuminatum }\end{array}$ & $\begin{array}{l}\text { brine shrimp: } 50 \mu \mathrm{g} \text { enniatin } \mathrm{B} / \mathrm{mL} \text { killed almost all after } 24 \mathrm{~h} \text {; } \\
\text { ranking in brine shrimps: enniatin } \mathrm{B}>\mathrm{B} 1>\mathrm{A} 1>\mathrm{A} \text {, mixture of all four most toxic [72] }\end{array}$ \\
\hline Equisetin & $\begin{array}{l}\text { F. equiseti } \\
\text { F. semitectum }\end{array}$ & $\begin{array}{l}\text { antibiotic activity against Gram-positive bacteria [73]; potent inhibitor of HIV-1 integrase } \\
\text { enzyme }[74] \\
\text { mice: } \mathrm{LD}_{50}: 63.0 \mathrm{mg} / \mathrm{kg} \mathrm{bw} \text {, intraperitoneal [73] }\end{array}$ \\
\hline
\end{tabular}


Table 3. Cont.

\begin{tabular}{|c|c|c|}
\hline Metabolite & Produced by & Effects \\
\hline Moniliformin & $\begin{array}{l}\text { F. avenaceum } \\
\text { F. subglutinans } \\
\text { F. proliferatum } \\
\text { F. oxysporum } \\
\text { F. fusariodes }\end{array}$ & $\begin{array}{l}\text { 1-day-old chicks: } \mathrm{LD}_{50}: 5.4 \mathrm{mg} / \mathrm{kg} \text { bw oral [75] } \\
\text { 7-weeks-old broilers: } \mathrm{LD}_{50}: 1.38 \mathrm{mg} / \mathrm{kg} \text { bw, intravenous [76] } \\
\text { broilers: } 50 \mathrm{mg} / \mathrm{kg} \text { feed toxic for broilers fed to market age, resulting in lower body weight gain, } \\
\text { less efficient feed converting rate, higher mortality [77]; additive effects with aflatoxin [78], as } \\
\text { well as with deoxynivalenol [79] } \\
\text { turkeys: } 37.5 \mathrm{mg} / \mathrm{kg} \text { feed hepatotoxic; } 25 \mathrm{mg} / \mathrm{kg} \text { feed cardiotoxic [77] } \\
\text { swine: } 100 \mathrm{mg} / \mathrm{kg} \text { feed for } 28 \text { days in growing barrows reduced body weight, body weight gain } \\
\text { and feed consumption and affected serum biochemical analytes; } 50 \mathrm{mg} / \mathrm{kg} \text { feed influence on } \\
\text { haematologic values [80]; additive effects with fumonisin } \mathrm{B}_{1} \text { [81] } \\
\text { sheep: } 10 \mathrm{mg} / \mathrm{kg} \text { bw, intubation caused death after } 18 \mathrm{~h} \text {, also degeneration of the proximal } \\
\text { tubules of kidneys [82] }\end{array}$ \\
\hline Tentoxin & $\begin{array}{l}\text { Alternaria } \\
\text { alternata }\end{array}$ & induces chlorosis in germinating seedlings of many dicotyledonous plants [64] \\
\hline $\begin{array}{l}\text { Tenuazonic } \\
\text { acid }\end{array}$ & $\begin{array}{l}\text { Alternaria } \text { sp. } \\
\text { A. alternata } \\
\text { A. triticina } \\
\text { A. tenuis } \\
\text { A. arborescens }\end{array}$ & $\begin{array}{l}\text { mice: } \\
\mathrm{LD}_{50}: 81 \mathrm{mg} / \mathrm{kg} \text { bw oral, female; } 186 \mathrm{mg} / \mathrm{kg} \text { bw oral, male [83]; } \\
\text { risk for oesophageal cancer: toxic effect on oesophageal mucosa of mice }(25 \mathrm{mg} / \mathrm{kg} \text { bw/day oral } \\
\text { for } 10 \mathrm{months}) \text { stronger than with alternariol methyl ether }(100 \mathrm{mg} / \mathrm{kg} \text { bw/day oral for } \\
10 \text { months } \text { - resulting in weight loss and lower feed consumption [36] } \\
\text { rats: } \mathrm{LD}_{50}: 168 \mathrm{mg} / \mathrm{kg} \text { bw oral, female; } 180 \mathrm{mg} / \mathrm{kg} \text { bw oral, male [83] } \\
\text { young chicken: } \mathrm{LD}_{50}: 37.5 \mathrm{mg} / \mathrm{kg} \text { bw oral [84] } \\
1.25-1.50 \mathrm{mg} / \mathrm{kg} \text { bw/day (3-weeks oral) induced microscopic and macroscopic lesions in various } \\
\text { tissues and significant weight loss [84] }\end{array}$ \\
\hline Tryptophol & $\begin{array}{l}\text { Candida } \\
\text { albicans } \\
\text { Acremonium } \\
\text { lolii }\end{array}$ & $\begin{array}{l}\text { in vitro: } \\
\text { cytotoxic, cytostatic, genotoxic effects in lymphocytes [85]; } 2 \mathrm{mM}(24 \mathrm{~h}) \text { damages DNA in } \\
\text { HepG2, A549 and THP-1 cells (comet-assay) [86]; induction of apoptosis in leukaemic blood } \\
\text { monocytes cell line U937 [87] } \\
\text { mice: } \mathrm{LD}_{50}: 351 \mathrm{mg} / \mathrm{kg} \text { bw, intraperitoneal [88] }\end{array}$ \\
\hline
\end{tabular}

As for the Alternaria metabolites alternariol, alternariol methyl ether, tenuazonic acid and tentoxin, only the first three are of toxicological concern. Tentoxin exhibits herbicidal properties [64,89], as it induces chlorosis by inhibiting chloroplast development [64]. It does not even figure in some reviews on Alternaria mycotoxins (e.g., Scott [90]) or is mentioned in passing as co-occurring with more important toxins, such as alternariol or alternariol methyl ether [33,91]. Alternariol and alternariol methyl ether have received some attention, due to their mutagenic and genotoxic properties. Their acute toxicity is rather low $[33,90,91]$. Tenuazonic acid is considered the most acutely toxic of the Alternaria mycotoxins [92]. Exposure to sub-lethal levels of tenuazonic acid $(10 \mathrm{mg} / \mathrm{kg})$ negatively affects feed efficiency in chicken and causes lesions on various organs [84]. The occurrence of Alternaria mycotoxins in food and feed in general was not deemed a significant health hazard in a report submitted to the European Food Safety Authority (EFSA), owing to the low naturally occurring contamination levels [93]. The EFSA panel on contaminants in the food chain (CONTAM) stated that a risk assessment for Alternaria mycotoxins in feed was not possible, due to a lack of information on occurrence and toxicity [94]. 
Data on culmorin and its hydroxylated analogues do not indicate acute toxicity to mammals [61]. Moniliformin (MON) in vivo toxicity has been investigated more extensively. Poultry seem to be the most sensitive species. The main acute symptoms are muscular weakness, respiratory stress and myocardial degeneration [29], and chronic exposure will result in reduced weight gain, impaired immune system and myocardial lesions [65]. Following a study on 270 male broiler chicks, Ledoux et al. [95] concluded that feed containing $>50 \mathrm{mg} / \mathrm{kg}$ MON will exert toxic effects on these animals. The concentrations observed in this study are well below this limit. In fact, occurrence data summarised in the report submitted to EFSA suggest that naturally contaminated samples do not normally exhibit contamination at such a high level. Studies reporting MON concentrations near or exceeding this proposed tolerance level usually refer to contamination in handpicked, visibly Fusarium-damaged samples [93].

\section{Experimental Section}

\subsection{Samples}

From 2010 on, a total number of 83 naturally contaminated samples of feed and feed raw materials were analysed with a semi-quantitative multi-mycotoxin LC-MS/MS method. The majority of the samples were feed samples $(n=35)$. Besides, samples of silage $(n=21)$, maize $(n=15)$, wheat and wheat by-products $(n=6)$, barley straw $(n=3)$ and other feed ingredients (soybeans, sunflower seeds etc., $n=3)$ were tested. The majority of the samples were sourced in Europe $(n=71)$, most often originating from Hungary $(n=19)$, Austria $(n=17)$ and Denmark $(n=15)$. Other European samples were obtained in Belgium, Italy, Norway, Russia, the UK and Ukraine. The remainder of the samples was sourced in America ( $n=8$, from Brazil, Canada and the USA) and Australia $(n=4)$. The pool of samples comprised a small number of samples $(n=9)$ that were known or expected to contain high levels of mycotoxins. These were three samples of US maize that had been found to contain high levels of DON $(n=2)$ or AF and FB $(n=1)$ using "conventional" HPLC analysis and six samples of maize cobs displaying different degrees of visible mould infection. The maize cob samples were all taken from the same field in Lower Austria in the $2010(n=2)$ and $2012(n=4)$ growing season.

\subsection{Analysis}

The analyses were conducted at IFA-Tulln. All samples were analysed for the presence and concentrations of fungal metabolites by LC-MS/MS according to Vishwanath et al. [8]. The analytical method has been extended to cover 320 metabolites, transferred to a more sensitive mass spectrometer and pre-validated for four matrices [96]. In brief, $5 \mathrm{~g}$ of sample was weighed into a $50 \mathrm{~mL}$ polypropylene tube (Sarstedt, Nürnbrecht, Germany) and extracted with $20 \mathrm{~mL}$ acetonitrile/water/acetic acid $(79: 20: 1, v / v / v)$ for $90 \mathrm{~min}$ on a GFL 3017 rotary shaker (GFL, Burgwedel, Germany). Extracts were diluted in extraction solvent (ratio 1:1) and directly injected into the LC-MS/MS instrument.

Chromatographic separation was performed at $25{ }^{\circ} \mathrm{C}$ on a Gemini ${ }^{\circledR} \mathrm{C}_{18}$-column, $150 \times 4.6 \mathrm{~mm}$ i.d., $5 \mu \mathrm{m}$ particle size, equipped with a $\mathrm{C}_{18} 4 \times 3 \mathrm{~mm}$ i.d. security guard cartridge (all from Phenomenex, Torrence, CA, USA) and coupled to an 1290 Series HPLC System (Agilent, Waldbronn, Germany). 
Chromatographic separation was performed at $25^{\circ} \mathrm{C}$ on a Gemini ${ }^{\circledR} \mathrm{C} 18$ column (Phenomenex, Torrance, CA, USA). After an initial time of $2 \mathrm{~min}$ at $100 \%$ eluent A, the proportion of eluent B was increased linearly to $50 \%$ within $2-5 \mathrm{~min}$ and $100 \%$ within $5-14 \mathrm{~min}$, followed by a holding-time of 4 min at $100 \%$ eluent $\mathrm{B}$ and 2.5 min column re-equilibration at $100 \%$ eluent A pumped at a flow rate of $1 \mathrm{~mL} / \mathrm{min}$.

A QTrap 5500 LC-MS/MS System (Applied Biosystems, Foster City, CA, USA) equipped with a TurboIonSpray electrospray ionization (ESI) source was used to detect and quantify the fungal metabolites. ESI-MS/MS was performed in the scheduled multiple reaction monitoring (sMRM) mode, both in positive and negative polarities in two separate chromatographic runs per sample by scanning two fragmentation reactions per analyte with the following settings: source temperature $550{ }^{\circ} \mathrm{C}$; curtain gas $30 \mathrm{psi}$; ion source gas 1 (sheath gas) 80 psi, ion source gas 2 (drying gas) 80 psi, ion spray voltage $-4500 \mathrm{~V}$ and $+5500 \mathrm{~V}$, respectively, collision gas (nitrogen) medium. The MRM detection windows were 54 and $96 \mathrm{~s}$ in the positive and negative ionization mode, respectively, and the cycle time was set to one second.

Mycotoxins were quantified by external calibration ( $1 / x$ weighted) using a multi-component standard prepared from authentic standards.

\section{Conclusions}

Multi-mycotoxin LC-MS/MS analysis is a valuable tool for obtaining a more accurate picture of mycotoxin contamination pattern in feed and feed raw materials. Key advantages of such methods are the detection of masked mycotoxins and the detection of mycotoxins that are usually not tested for.

Mycotoxin conjugates can make up a significant proportion of the total mycotoxin contamination, particularly regarding DON and ZEN [27]. In view of the possible reconversion of some mycotoxin conjugates (e.g., DON-3-Glc and ZEN-4-sulfate) to the parent toxin during digestion the occurrence of high proportions of masked mycotoxins might add significantly to the toxicity of the feed. Yet, little is known about the extent of masked mycotoxin reconversion during digestion (recent results suggest low bioavailability in rats [28]), and more research is needed in this field.

The total number of detected metabolites amounts to 139, which is about twice as high as in previous studies applying the same method to African food and feed samples [21,22]. Yet, evaluating the risk associated with the presence of a given analyte proves difficult for the vast majority of the metabolites. Table 3 highlights the lack of toxicity data on these substances and the need for further research in this area. As exposure to acutely toxic concentrations is less common than chronic exposure to low levels of a metabolite, potential adverse effects of long-term low-level exposure should be the focus of future research efforts.

The co-occurrence of seven to 69 metabolites per sample further complicates the evaluation of the feed material's toxicological potential. Additive and synergistic effects on overall toxicity are frequently observed when mycotoxin mixtures are evaluated instead of single toxins. This is particularly true at sub-acute concentrations considering that most studies investigating the effect of mycotoxin combinations on animal performance at these levels found additive or synergistic effects [97]. In addition, naturally DON contaminated feed frequently proved more toxic than artificially contaminated feed containing the same concentration of the toxin $[98,99]$. This testifies to 
the fact that interactions of co-occurring metabolites can enhance the overall toxic effect of single mycotoxins. Consequently, data on the interactions of "novel" mycotoxins and other metabolites with each other and with regulated mycotoxins (AF, FB, DON, ZEN and OTA) are needed.

In conclusion, multi-mycotoxin LC-MS/MS analysis is an important step towards gaining a more accurate picture of the extent of mycotoxin contamination in agricultural commodities, food and feed. However, highlighting the frequent occurrence of both masked and usually neglected "emerging" mycotoxins, the results of such analyses also emphasise the fact that considerable research effort is still required in this field. In order to permit an accurate assessment of the risks associated with the presence of these contaminants more data is needed on their metabolic fate (particularly concerning masked mycotoxins), their toxicities and possible synergistic interactions with other mycotoxins present.

\section{Conflict of Interest}

The authors declare no conflict of interest.

\section{References}

1. Frisvad, J.C.; Thrane, U.; Samson, R.A.; Pitt, J.I. Important mycotoxins and the fungi which produce them. Adv. Exp. Med. Biol. 2006, 571, 3-31.

2. Binder, E.M. Managing the risk of mycotoxins in modern feed production. Anim. Feed Sci. Technol. 2007, 133, 149-166.

3. Bryden, W.L. Mycotoxin contamination of the feed supply chain: Implications for animal productivity and feed security. Anim. Feed Sci. Technol. 2012, 173, 134-158.

4. Berthiller, F.; Sulyok, M.; Krska, R.; Schuhmacher, R. Chromatographic methods for the simultaneous determination of mycotoxins and their conjugates in cereals. Int. J. Food Microbiol. 2007, 119, 33-37.

5. Sulyok, M.; Berthiller, F.; Krska, R.; Schuhmacher, R. Development and validation of a liquid chromatography/tandem mass spectrometric method for the determination of 39 mycotoxins in wheat and maize. Rapid Commun. Mass Spectrom. 2006, 20, 2649-2659.

6. Sulyok, M.; Krska, R.; Schuhmacher, R. A liquid chromatography/tandem mass spectrometric multi-mycotoxin method for the quantification of 87 analytes and its application to semi-quantitative screening of moldy food samples. Anal. Bioanal. Chem. 2007, 389, 1505-1523.

7. Sulyok, M.; Krska, R.; Schuhmacher, R. Application of an LC-MS/MS based multi-mycotoxin method for the semi-quantitative determination of mycotoxins occurring in different types of food infected by moulds. Food Chem. 2010, 119, 408-416.

8. Vishwanath, V.; Sulyok, M.; Labuda, R.; Bicker, W.; Krska, R. Simultaneous determination of 186 fungal and bacterial metabolites in indoor matrices by liquid chromatography/tandem mass spectrometry. Anal. Bioanal. Chem. 2009, 395, 1355-1372.

9. Berthiller, F.; Schuhmacher, R.; Adam, G.; Krska, R. Formation, determination and significance of masked and other conjugated mycotoxins. Anal. Bioanal. Chem. 2009, 395, 1243-1252. 
10. Gareis, M.; Bauer, J.; Thiem, J.; Plank, G.; Grabley, S.; Gedek, B. Cleavage of zearalenone-glycoside, a "masked" mycotoxin, during digestion in swine. J. Vet. Med. 1990, 37, 236-240.

11. Plasencia, J.; Mirocha, C.J. Isolation and characterization of zearalenone sulfate produced by Fusarium spp. Appl. Environ. Microbiol. 1991, 57, 146-150.

12. Berthiller, F.; Krska, R.; Domig, K.J.; Kneifel, W.; Juge, N.; Schuhmacher, R.; Adam, G. Hydrolytic fate of deoxynivalenol-3-glucoside during digestion. Toxicol. Lett. 2011, 206, 264-267.

13. Vendl, O.; Berthiller, F.; Crews, C.; Krska, R. Simultaneous determination of deoxynivalenol, zearalenone, and their major masked metabolites in cereal-based food by LC-MS-MS. Anal. Bioanal. Chem. 2009, 395, 1347-1354.

14. Binder, E.M.; Tan, L.M.; Chin, L.J.; Handl, J.; Richard, J. Worldwide occurrence of mycotoxins in commodities, feeds and feed ingredients. Anim. Feed Sci. Technol. 2007, 137, 265-282.

15. Borutova, R.; Acosta Aragon, Y.; Nährer, K.; Berthiller, F. Co-occurrence and statistical correlations between mycotoxins in feedstuffs collected in the Asia-Oceania Region in 2010. Anim. Feed Sci. Technol. 2012, 178, 190-197.

16. Rodrigues, I.; Chin, L.J. A comprehensive survey on the occurrence of mycotoxins in maize dried distillers' grain and solubles sourced worldwide. World Mycotoxin J. 2012, 5, 83-88.

17. Rodrigues, I.; Handl, J.; Binder, E.M. Mycotoxin occurrence in commodities, feeds and feed ingredients sourced in the Middle East and Africa. Food Addit. Contam. B 2011, 4, 168-179.

18. Rodrigues, I.; Naehrer, K. A three-year survey on the worldwide occurrence of mycotoxins in feedstuffs and feed. Toxins 2012, 4, 663-675.

19. Griessler, K.; Rodrigues, I.; Handl, J.; Hofstetter, U. Occurrence of mycotoxins in Southern Europe. World Mycotoxin J. 2010, 3, 301-309.

20. Rodrigues, I.; Naehrer, K. Prevalence of mycotoxins in feedstuffs and feed surveyed worldwide in 2009 and 2010. Phytopathol. Mediterr. 2012, 51, 175-192.

21. Ezekiel, C.N.; Bandyopadhyay, R.; Sulyok, M.; Warth, B.; Krska, R. Fungal and bacterial metabolites in commercial poultry feed from Nigeria. Food Addit. Contam. A 2012, 29, 1288-1299.

22. Warth, B.; Parich, A.; Atehnkeng, J.; Bandyopadhyay, R.; Schuhmacher, R.; Sulyok, M.; Krska, R. Quantitation of mycotoxins in food and feed from burkina faso and mozambique using a modern LC-MS/MS multitoxin method. J. Agric. Food Chem. 2012, 60, 9352-9363.

23. Placinta, C.M.; D’Mello, J.P.F.; Macdonald, A.M.C. A review of worldwide contamination of cereal grains and animal feed with Fusarium mycotoxins. Anim. Feed Sci. Technol. 1999, 78, 21-37.

24. Bottalico, A. Fusarium diseases of cereals: Species complex and related mycotoxin profiles in Europe. J. Plant Pathol. 1998, 80, 85-103.

25. European Commission. Commission Regulation (EU) No $165 / 2010$ Amending Regulation (EC) No 1881/2006 Setting Maximum Levels for Certain Contaminants in Foodstuffs as Regards Aflatoxins; Commission Regulation (EU) No 178/2010; European Union: Brussels, Belguim, 2010; pp. 1-5. 
26. European Union. European Commission (2006/576/EU) of 17 August 2006 on the Presence of Deoxynivalenol, Zearalenone, Ochratoxin A, T-2 and HT-2 and Fumonisins in Products Intended for Animal Feeding. Off. J. Eur. Un. 2006, L229, 7-9.

27. De Boevre, M.; di Mavungu, J.D.; Landschoot, S.; Audenaert, K.; Eeckhout, M.; Maene, P.; Haesaert, G.; de Saeger, S. Natural occurrence of mycotoxins and their masked forms in food and feed products. World Mycotoxin J. 2012, 5, 207-219.

28. Nagl, V.; Schwartz, H.; Krska, R.; Moll, W.-D.; Knasmüller, S.; Ritzmann, M.; Adam, G.; Berthiller, F. Metabolism of the masked mycotoxin deoxynivalenol-3-glucoside in rats. Toxicol. Lett. 2012, 213, 367-373.

29. Jestoi, M. Emerging Fusarium-mycotoxins fusaproliferin, beauvericin, enniatins, and moniliformin-A review. Crit. Rev. Food Sci. Nutr. 2008, 48, 21-49.

30. Chang, M.-H.; Huang, F.-J.; Chan, W.-H. Emodin induces embryonic toxicity in mouse blastocysts through apoptosis. Toxicology 2012, 299, 25-32.

31. Wei, W.T.; Chen, H.; Ni, Z.L.; Liu, H.B.; Tong, H.F.; Fan, L.; Liu, A.; Qiu, M.X.; Liu, D.L.; Guo, H.C.; et al. Antitumor and apoptosis-promoting properties of emodin, an anthraquinone derivative from Rheum officinale Baill, against pancreatic cancer in mice via inhibition of Akt activation. Int. J. Oncol. 2011, 39, 1381-1390.

32. Feng, Y.; Huang, S.-L.; Dou, W.; Zhang, S.; Chen, J.-H.; Shen, Y.; Shen, J.-H.; Leng, Y. Emodin, a natural product, selectively inhibits $11 \beta$-hydroxysteroid dehydrogenase type 1 and ameliorates metabolic disorder in diet-induced obese mice. Brit. J. Pharmacol. 2010, 161, 113-126.

33. Ostry, V. Alternaria mycotoxins: An overview of chemical characterization, producers, toxicity, analysis and occurrence in foodstuffs. World Mycotoxin J. 2008, 1, 175-188.

34. Griffin, G.F.; Chu, F.S. Toxicity of the Alternaria metabolites alternariol, alternariol methyl ether, altenuene, and tenuazonic acid in the chicken embryo assay. Appl. Environ. Microbiol. 1983, 46, 1420-1422.

35. Tiemann, U.; Tomek, W.; Schneider, F.; Müller, M.; Pöhland, R.; Vanselow, J. The mycotoxins alternariol and alternariol methyl ether negatively affect progesterone synthesis in porcine granulosa cells in vitro. Toxicol. Lett. 2009, 186, 139-145.

36. Yekeler, H.; Bitmiş, K.; Ozçelik, N.; Doymaz, M.Z.; Çalta, M. Analysis of toxic effects of Alternaria toxins on esophagus of mice by light and electron microscopy. Toxicol. Pathol. 2001, 29, 492-497.

37. Darkin-Rattray, S.J.; Gurnett, A.M.; Myers, R.W.; Dulski, P.M.; Crumley, T.M.; Allocco, J.J.; Cannova, C.; Meinke, P.T.; Colletti, S.L.; Bednarek, M.A.; et al. Apicidin: A novel antiprotozoal agent that inhibits parasite histone deacetylase. Proc. Natl. Acad. Sci. USA 1996, 93, 13143-13147.

38. Han, J.-W.; Ahn, S.H.; Park, S.H.; Wang, S.Y.; Bae, G.-U.; Seo, D.-W.; Kwon, H.-K.; Hong, S.; Lee, H.Y.; Lee, Y.-W.; Lee, H.-W. Apicidin, a histone deacetylase inhibitor, inhibits proliferation of tumor cells via induction of p21WAF1/Cip1 and gelsolin. Cancer Res. 2000, 60, 6068-6074.

39. Cheong, J.-W.; Chong, S.Y.; Kim, J.Y.; Eom, J.I.; Jeung, H.K.; Maeng, H.Y.; Lee, S.T.; Min, Y.H. Induction of apoptosis by apicidin, a histone deacetylase inhibitor, via the activation of mitochondria-dependent caspase cascades in human Bcr-Abl-positive leukemia cells. Clin. Cancer Res. 2003, 9, 5018-5027. 
40. Park, J.-S.; Lee, K.-R.; Kim, J.-C.; Lim, S.-H.; Seo, J.-A.; Lee, Y.-W. A hemorrhagic factor (apicidin) produced by toxic Fusarium isolates from soybean seeds. Appl. Environ. Microbiol. 1999, 65, 126-130.

41. Kotyk, A.N.; Trufanova, V.; Breslavets, V.A. A syndrome of changing egg quality. Bull. Ukr. Poult. Res. Insitute Kharkov 1990, 29, 41-42.

42. Kotyk, A.N.; Trufanova, V.; Brestlavets, V.A.; Metasheva, Z.T. Egg Quality in Rhode Island Red Hens Fed by Fusarium graminearum Culture. In Proceedings of 6th European Symposium on the Quality of Eggs and Egg products, Zaragoza, Spain, 1995; pp. 263-266.

43. Dvorska, J.E. Effect of Dimeric Naphthoquinone Aurofusarin on Chicken Meat Quality. In Proceedings of 21st World's Poultry Congress, Montreal, Canada, 2000; pp. 46-49.

44. Dvorska, J.E.; Surai, P.F.; Speake, B.K.; Sparks, N.H.C. Effect of the mycotoxin aurofusarin on the antioxidant composition and fatty acid profile of quail eggs. Brit. Poult. Sci. 2001, 42, 643-649.

45. Sakhatsky, I.M.; Trufanova, V.O. Effect of Fusarium Mycotoxins Present in Laying Hens Ration on Immune System Function in Progeny Chicks. In Proceedings of 21st World's Poultry Congress; Montreal, Canada, 2000.

46. Logrieco, A.; Moretti, A.; Castella, G.; Kostecki, M.; Golinski, P.; Ritieni, A.; Chelkowski, J. Beauvericin production by Fusarium species. Appl. Environ. Microbiol. 1998, 64, 3084-3088.

47. Logrieco, A.; Rizzo, A.; Ferracane, R.; Ritieni, A. Occurrence of beauvericin and enniatins in wheat affected by Fusarium avenaceum head blight. Appl. Environ. Microbiol. 2002, 68, 82-85.

48. Wang, Q.; Xu, L. Beauvericin, a bioactive compound produced by fungi: A short review. Molecules 2012, 17, 2367-2377.

49. Tonshin, A.A.; Teplova, V.V.; Andersson, M.A.; Salkinoja-Salonen, M.S. The Fusarium mycotoxins enniatins and beauvericin cause mitochondrial dysfunction by affecting the mitochondrial volume regulation, oxidative phosphorylation and ion homeostasis. Toxicology 2010, 276, 49-57.

50. Morrison, E.; Kosiak, B.; Ritieni, A.; Aastveit, A.H.; Uhlig, S.; Bernhoft, A. Mycotoxin production by Fusarium avenaceum strains isolated from norwegian grain and the cytotoxicity of rice culture extracts to porcine kidney epithelial cells. J. Agric. Food Chem. 2002, 50, 3070-3075.

51. Finefield, J.M.; Frisvad, J.C.; Sherman, D.H.; Williams, R.M. Fungal origins of the bicyclo[2.2.2]diazaoctane ring system of prenylated indole alkaloids. J. Nat. Prod. 2012, 75, 812-833.

52. Frisvad, J.C.; Rank, C.; Nielsen, K.F.; Larsen, T.O. Metabolomics of Aspergillus fumigatus. Med. Mycol. 2009, 47, S53-S71.

53. Amar, M.B.; Elleuch, L.; Abd-Alla, H.I.; Najah, S.; Chakchouk, A.; Damak, M.; Ben Salem, R.; Shaaban, M.; Mellouli, L. The new Streptomyces sp. TN605 strain secretes simultaneously three active compounds and a high level of the interesting pharmaceutical industry intermediate: 2-hydroxyphenylacetic acid. Bull. Environ. Pharmacol. Life Sci. 2012, 1, 48-56.

54. Yang, H.-Y.; Wang, Y.-M.; Peng, S.-Q. Metallothionein-I/II null cardiomyocytes are sensitive to Fusarium mycotoxin butenolide-induced cytotoxicity and oxidative DNA damage. Toxicon 2010, $55,1291-1296$. 
55. Wang, Y.-M.; Wang, H.-J.; Peng, S.-Q. In ovo exposure of a Fusarium mycotoxin butenolide induces hepatic and renal oxidative damage in chick embryos, and antioxidants provide protections. Toxicol. in Vitro 2009, 23, 1354-1359.

56. Guo, J.; Zhang, L.-S.; Wang, Y.-M.; Yan, C.-H.; Huang, W.-P.; Wu, J.; Yuan, H.-T.; Lin, B.-W.; Shen, J.-L.; Peng, S.-Q. Study of embryotoxicity of Fusarium mycotoxin butenolide using a whole rat embryo culture model. Toxicol. in Vitro 2011, 25, 1727-1732.

57. Kosuri, N.R.; Grove, M.D.; Yates, S.G.; Tallent, W.H.; Ellis, J.J.; Wolff, I.A.; Nichols, R.E. Response of cattle to mycotoxins of Fusarium tricinctum isolated from corn and fescue. J. Am. Vet. Med. Assoc. 1970, 157, 938-940.

58. Zhang, Y.-F.; Xiao, K.; Chandramouli, K.H.; Xu, Y.; Pan, K.; Wang, W.-X.; Qian, P.-Y. Acute toxicity of the antifouling compound butenolide in non-target organisms. PLoS One 2011, 6, e23803.

59. Burmeister, H.R.; Grove, M.D.; Kwolek, W.F. Moniliformin and butenolide: Effect on mice of high-level, long-term oral intake. Appl. Environ. Microbiol. 1980, 40, 1142-1144.

60. Tookey, H.L.; Yates, S.G.; Ellis, J.J.; Grove, M.D.; Nichols, R.E. Toxic effects of a butenolide mycotoxin and of Fusarium tricinctum cultures in cattle. J. Am. Vet. Med. Assoc. 1972, 160, $1522-1526$.

61. Pedersen, P.B.; Miller, D.J. The fundal metabolite culmorin and related compounds. Nat. Toxins 1999, 7, 305-309.

62. Ghembremeskel, M.; Langseth, W. The occurrence of culmorin and hydroxy-culmorins in cereals. Mycopathologia 2000, 152, 103-108.

63. Rotter, R.G.; Thompson, B.K.; Trenholm, H.L.; Prelusky, D.B.; Hartin, K.E.; Miller, J.D. A preliminary examination of potential interactions between deoxynivalenol (DON) and other selected Fusarium metabolites in growing pigs. Can. J. Anim. Sci. 1992, 72, 102-116.

64. Duke, S.O.; Dayan, F.E. Modes of action of microbially-produced phytotoxins. Toxins 2011, 3, 1038-1064.

65. Jestoi, M.; Kokkonen, M.; Uhlig, S. What about the "other" Fusarium mycotoxins? World Mycotoxin J. 2009, 2, 181-192.

66. Duerksen-Hughes, P.J.; Yang, J.; Ozcan, O. p53 Induction as a genotoxic test for twenty-five chemicals undergoing in vivo carcinogenicity testing. Environ. Health Perspect. 1999, 107, 805-812.

67. Wells, J.M.; Cole, R.J.; Kirksey, J.W. Emodin, a toxic metabolite of Aspergillus wentii isolated from weevil-damaged chestnuts. Appl. Microbiol. 1975, 30, 26-28.

68. He, Q.; Liu, K.; Wang, S.; Hou, H.; Yuan, Y.; Wang, X. Toxicity induced by emodin on zebrafish embryos. Drug Chem. Toxicol. 2012, 35, 149-154.

69. Santini, A.; Meca, G.; Uhlig, S.; Ritieni, A. Fusaproliferin, beauvericin and enniatins: Occurrence in food-A review. World Mycotoxin J. 2012, 5, 71-81.

70. Tedjiotsop Feudjio, F.; Dornetshuber, R.; Lemmens, M.; Hoffmann, O.; Lemmens-Gruber, R.; Berger, W. Beauvericin and enniatin: Emerging toxins and/or remedies? World Mycotoxin J. 2010, 3, 415-430. 
71. McKee, T.C.; Bokesch, H.R.; McCormick, J.L.; Rashid, M.A.; Spielvogel, D.; Gustafson, K.R.; Alavanja, M.M.; Cardellina, J.H.; Boyd, M.R. Isolation and characterization of new anti-HIV and cytotoxic leads from plants, marine, and microbial organisms1. J. Nat. Prod. 1997, 60, 431-438.

72. Tan, D.C.; Flematti, G.R.; Ghisalberti, E.L.; Sivasithamparam, K.; Barbetti, M.J. Toxigenicity of enniatins from western Australian Fusarium species to brine shrimp (Artemia franciscana). Toxicon 2011, 57, 817-825.

73. Burmeister, H.R. Antibiotic Equisetin and Methods of Production. US3959468A, 6 May 1974.

74. Burke, L.T.; Dixon, D.J.; Ley, S.V.; Rodríguez, F. Total synthesis of the Fusarium toxin equisetin. Org. Biomol. Chem. 2005, 3, 274-280.

75. Burmeister, H.R.; Ciegler, A.; Vesonder, R.F. Moniliformin, a metabolite of Fusarium moniliforme NRRL 6322: Purification and toxicity. Appl. Environ. Microbiol. 1979, 37, $11-13$.

76. Allen, N.K.; Burmeister, H.R.; Weaver, G.A.; Mirocha, C.J. Toxicity of dietary and intravenously administered moniliformin to broiler chickens. Poult. Sci. 1981, 60, 1415-1417.

77. Broomhead, J.; Ledoux, D.R.; Bermudez, A.J.; Rottinghaus, G.E. Chronic effects of moniliformin in broilers and turkeys fed dietary treatments to market age. Avian Dis. 2002, 46, 901-908.

78. Kubena, L.F.; Harvey, R.B.; Buckley, S.A.; Edrington, T.S.; Rottinghaus, G.E. Individual and combined effects of moniliformin present in Fusarium fujikuroi culture material and aflatoxin in broiler chicks. Poult. Sci. 1997, 76, 265-270.

79. Harvey, R.B.; Kubena, L.F.; Rottinghaus, G.E.; Turk, J.R.; Casper, H.H.; Buckley, S.A. Moniliformin from Fusarium fujikuroi culture material and deoxynivalenol from naturally contaminated wheat incorporated into diets of broiler chicks. Avian Dis. 1997, 41, 957-963.

80. Harvey, R.B.; Edrington, T.S.; Kubena, L.F.; Rottinghaus, G.E.; Turk, J.R.; Genovese, K.J.; Nisbet, D.J. Toxicity of moniliformin from Fusarium fujikuroi culture material to growing barrows. J. Food Prot. 2001, 64, 1780-1784.

81. Harvey, B.; Edrington, T.S.; Kubena, L.F.; Rottinghaus, G.E.; Turk, J.R.; Genovese, K.J.; Ziprin, R.L.; Nisbet, D.J. Toxicity of fumonisin from Fusarium verticillioides culture material and moniliformin from Fusarium fujikuroi culture material when fed singly and in combination to growing barrows. J. Food Prot. 2002, 65, 373-377.

82. Lamprecht, S.C.; Marasas, W.F.O.; Thiel, P.G.; Schneider, D.J.; Knox-Davies, P.S. Incidence and toxigenicity of seedborne Fusarium species from annual Medicago species in South Africa. Phytopathology 1986, 76, 1040-1042.

83. Pero, R.W.; Posner, H.; Blois, M.; Harvan, D.; Spalding, J.W. Toxicity of metabolites produced by the "Alternaria". Environ. Health Perspect. 1973, 4, 87-94.

84. Giambrone, J.J.; Davis, N.D.; Diener, U.L. Effect of tenuazonic acid on young chickens. Poult. Sci. 1978, 57, 1554-1558.

85. Kosalec, I.; Safranic, A.; Pepeljnjak, S.; Bacun-Druzina, V.; Ramic, S.; Kopjar, N. Genotoxicity of tryptophol in a battery of short-term assays on human white blood cells in vitro. Basic Clin. Pharmacol. Toxicol. 2008, 102, 443-452.

86. Kosalec, I.; Ramić, S.; Jelić, D.; Antolović, R.; Pepeljnjak, S.; Kopjar, N. Assessment of tryptophol genotoxicity in four cell lines in vitro: A pilot study with alkaline comet assay. Arch. Ind. Hyg. Toxicol. 2011, 62, 41-49. 
87. Inagaki, S.; Morimura, S.; Tang, Y.; Akutagawa, H.; Kida, K. Tryptophol induces death receptor (DR) 5-mediated apoptosis in U937 cells. Biosci. Biotechnol. Biochem. 2007, 71, 2065-2068.

88. Bosin, T.R.; Campaigne, E.; Dinner, A.; Rogers, R.B.; Maickel, R.P. Comparative toxicological studies of indole, benzo[b]thiophene, and 1-methylindole derivatives. J. Toxicol. Environ. Health 1976, 1, 515-520.

89. Bräse, S.; Encinas, A.; Keck, J.; Nising, C.F. Chemistry and biology of mycotoxins and related fungal metabolites. Chem. Rev. 2009, 109, 3903-3990.

90. Scott, P.M. Analysis of agricultural commodities and foods for alternaria mycotoxins. J. AOAC Int. 2001, 84, 1809-1817.

91. Logrieco, A.; Moretti, A.; Solfrizzo, M. Alternaria toxins and plant diseases: An overview of origin, occurrence and risk. World Mycotoxin J. 2009, 2, 129-140.

92. Weidenbörner, M. Encyclopedia of Food Mycotoxins; Springer: Berlin, Germany, 2001; p. 249.

93. Battilani, P.; Costa, L.G.; Dossena, A.; Gullino, M.L.; Marchelli, R.; Galaverna, G.; Pietri, A.; Dall'Asta, C.; Giorni, P.; Spadaro, D.; Gualla, A. CFP/EFSA/CONTAM/2008/01—Scientific Information on Mycotoxins and Natural Plant Toxicants. Available online: http://www.efsa.europa.eu/en/supporting/pub/24e.htm (accessed on 17 April 2012).

94. EFSA Panel on Contaminants in the Food Chain. Scientific opinion on the risks for animal and public health related to the presence of Alternaria toxins in feed and food. EFSA J. 2011, 9, 2407.

95. Ledoux, D.R.; Bermudez, A.J.; Roinghaus, G.E.; Broomhead, J.; Bennet, G.A. Effects of feeding Fusarium fujikuori culure material containing known levels of moniliformin in young broiler chicks. Poult. Sci. 1995, 74, 297-305.

96. Malachova, A.; Beltran, E.; Krska, R.; Sulyok, M. Validation of an LC-MS/MS multi-toxin method covering 329 fungal and bacterial metabolites for four commodities from different matrix groups specified in SANCO 12495/2011. J. Chromatogr. A 2013, to be submitted.

97. Grenier, B.; Oswald, I.P. Mycotoxin co-contamination of food and feed: Meta-analysis of publications describing toxicological interactions. World Mycotoxin J. 2011, 4, 285-313.

98. Dersjant-Li, Y.; Verstegen, M.W.A.; Gerrits, W.J.J. The impact of low concentrations of aflatoxin, deoxynivalenol or fumonisin in diets on growing pigs and poultry. Nutr. Res. Rev. 2003, $16,223-239$.

99. Trenholm, H.L.; Foster, B.C.; Charmley, L.L.; Thompson, B.K.; Hartin, K.E.; Coopock, R.W.; Albassam, M.A. Effects of feeding diets containing Fusarium (naturally) contaminated wheat or pure deoxynivalenol (DON) in growing pigs. Can. J. Anim. Sci. 1994, 74, 361-369.

(C) 2013 by the authors; licensee MDPI, Basel, Switzerland. This article is an open access article distributed under the terms and conditions of the Creative Commons Attribution license (http://creativecommons.org/licenses/by/3.0/). 